\title{
FAKTOR YANG MEMENGARUHI PERILAKU MASYARAKAT TERHADAP PEMBERANTASAN MALARIA
}

\author{
Fajar Hayati $i^{1^{*}}$, Ismail Efendy ${ }^{2}$, Asriwati ${ }^{3}$ \\ 1,2,3 IImu Kesehatan Masyarakat, Institut Kesehatan Helvetia \\ *Email: fajarhayati22@gmail.com
}

\begin{abstract}
ABSTRAK
Penyakit malaria merupakan salah satu masalah kesehatan di hampir seluruh belahan dunia, terutama di negaranegara beriklim tropik dan sub tropik, baik sebagai penyakit endemik maupun epidemik. Adapun tujuan penelitian ini yaitu untuk menganalisis faktor yang memengaruhi perilaku masyarakat dalam pemberantasan malaria diDesa Sekerak Kanan Kecamatan Sekerak Kabupaten Aceh Tamiang Tahun 2019.Jenis penelitian yang digunakan dalam penelitian ini adalah surveianalitik dengan rancangan cross sectional study yang bertujuan untuk menganalisis faktor yang memengaruhi perilaku masyarakat dalam pemberantasan malaria dengan model pendekatankuantitatif.Ada pengaruh pengetahuan $(p=0,045)$, sikap $(p=0,024)$, kemampuan ekonomi $(p=0,015)$, lingkungan tempat tinggal $(p=0,025)$, penyuluhan tenaga kesehatanmasyarakat $(p=0,005)$. Adapun variabel yang paling berpengaruh dalam pemberantasan malaria di Desa Sekerak Kanan Kecamatan Sekerak Kabupaten Aceh Tamiang Tahun 2019, yaitu variabel kemampuan ekonomi $(\mathrm{p}=0,008)$.Adapun kesimpulan dalam penelitian ini yaitu pengetahuan, sikap, kemampuan ekonomi, lingkungan tempat tinggal, penyuluhan tenaga kesehatanmasyarakat, berpengaruh dalam pemberantasan malaria di Desa Sekerak Kanan Kecamatan Sekerak Kabupaten Aceh Tamiang Tahun 2019. Sehingga disarankan agar masyarakat dapat meningkatkan wawasan, pengetahuan, keterampilan dalam mengumpulkan, mengolah, menganalisa serta menginformasikan data temuan tentang perilaku masyarakat dalam pemberantasan malaria.
\end{abstract}

Kata kunci: Pengetahuan, sikap, perilaku masyarakat, malaria

\begin{abstract}
Malaria is a health problem in almost all parts of the world, especially in tropical and sub-tropical countries, both endemic and epidemic. The purpose of this study is to analyze the factors that influence people's behavior in eradicating malaria in Sekerak Kanan Village, Sekerak District, Aceh Tamiang Regency in 2019. The research type used in this study is an analytic survey with a cross sectional study design that aims to analyze the factors that influence people's behavior in eradicating malaria with a quantitative approach model. There is the influence of knowledge $(p=0.045)$, attitude $(p=0.024)$, economic capacity $(p=0.015)$, neighborhood $(p=0.025)$, counseling of community health workers $(p=$ 0.005). The most influential variable in eradicating malaria inSekerak Kanan Village is Sekerak Subdistrict, Aceh Tamiang Regency in 2019, namely the economic capability variable $(p=0.008)$. The conclusion is knowledge, attitudes, economic capacity, neighborhood, counseling of public health workers are influential in eradicating malaria in Sekerak Kanan Village, Sekerak District, Aceh Tamiang Regency in 2019. So it is suggested that the community can increase their insight, knowledge, and skills in collect, process, analyze and inform data on findings about community behavior in eradicating malaria.
\end{abstract}

Keywords: Knowledge, attitude, community behavior, malaria

\section{PENDAHULUAN}

Penyakit malaria merupakan salah satu masalah kesehatan di hampir seluruh belahan dunia, terutama di negara-negara beriklim tropik dan sub tropik, baik sebagai penyakit endemik maupun epidemik.Penyakit malaria termasuk ke dalam Kejadian Luar Biasa (KLB).Penyakit ini disebabkan oleh infeksi protozoa genus Plasmodium yang ditularkan melalui gigitan nyamuk Anopheles betina yang terinfeksi sehingga dapat menyebabkan kematian. ${ }^{1}$

Berdasarkan data World Health Organization tahun 2018, diketahui bahwa dari tahun 2015 hingga tahun 2017 tidak ada kemajuan yang signifikan dalam mengurangi kasus penyakit malaria. Pada tahun 2015 diperkirakan sebanyak 214 juta kasus malaria dan sebanyak 435.000 kematian yang disebabkan oleh penyakit malaria tersebut. 
Jurnal Kesmas Prima Indonesia

Vol 2 No 1 (2020)

Tahun 2016 diperkirakan sebanyak 216 juta kasus dan sebanyak 445.000 kematian akibat malaria, sedangkan tahun 2017 kembali mengalami peningkatan yaitu 219 juta kasus malaria dan 435.000 kematian akibat malaria. ${ }^{2}$

Berdasarkan data Kementerian Kesehatan Republik Indonesia tahun 2018, diketahui bahwa, hingga akhir tahun 2017 terdapat 261.671 kasus malaria yang melanda Indonesia dan 100 orang di antaranya meninggal dunia. Tingginya prevelensi tersebut disebabkan oleh faktor lingkungan, karena $35 \%$ masyarakat Indonesia bertempat tinggal di daerah berisiko terinfeksi malaria, yang setiap tahunnya dilaporkan sebanyak 38 ribu orang meninggal dunia

Wabah malaria tersebut pun hampir terjadi setiap tahun di berbagai wilayah endemik Indonesia seperti, di Provinsi Nusa Tenggara Timur, Provinsi Nusa Tenggara Barat, Provinsi Maluku, Provinsi Maluku Utara, Provinsi Kalimantan Tengah, Provinsi Bangka Belitung, Provinsi Kepulauan Riau, dan Provinsi Bengkulu, Provinsi Jambi, Provinsi Sulawesi Tengah, Provinsi Sulawesi Barat, Provinsi Gorontalo, serta Provinsi Aceh. ${ }^{3}$

Untuk mengurangi wabah malaria tersebut, pemerintah Indonesia khususnya Kementerian Kesehatan Republik Indonesia tahun 2018 telah on the track dalam upaya eliminasi malaria pada tahun 2030. Pada tahun 2016 jumlah kabupaten/kota eliminasi malaria sebanyak 247 dari target 245. Pada tahun 2017, dari 514 jumlah kabupaten/kota di Indonesia, 266 (52\%) di antaranya merupakan wilayah bebas malaria, 172 kabupaten/kota (33\%) endemis rendah, 37 kabupaten/kota $(7 \%)$ endemis menengah, dan 39 kabupaten/kota (8\%) endemis tinggi. Sementara tahun 2018 ditargetkan sebanyak 285 kabupaten/kota yang berhasil mencapai eliminasi, dan 300 kabupaten/kota pada tahun 2019. Selain itu, pemerintah juga menargetkan tidak ada lagi daerah endemis tinggi malaria di tahun $2030{ }^{4}$

Eliminasi malaria itu sendiri merupakan upaya untuk menghentikan penularan malaria setempat, dalam satu wilayah geografis tertentu.Maksudnya, kasus malaria masih ada namun bukan didapat di daerah tersebut, dan bisa jadi masih ditemukan nyamuk penular malarianya, sehingga tetap dibutuhkan kewaspadaan petugas kesehatan, pemerintah, dan masyarakat untuk mencegah penularan kembali. ${ }^{5}$

Adapun upaya pemerintah dalam memperluas wilayah bebas malaria di antaranya
p-ISSN: 2355-164X

e-ISSN: 2721-110X

dilakukan melalui, pekan kelambu anti nyamuk massal dan pemantauan penggunaannya. Secara nasional, jumlah kelambu yang didistribusikan untuk seluruh Indonesia sejak tahun 2004 sampai tahun 2017 adalah sebanyak 27,6 juta kelambu. ${ }^{4}$

Rendahnya tingkat kepedulian masyarakat tersebut erat kaitannya dengan perilaku kesehatan individu masyarakat tersebut. Hal ini sesuai dengan pendapat Green yang menyatakan bahwa faktor-faktor yang berasal dari dalam diri individu dan lingkungan sekitar tempat tinggal individu sangat memengaruhi perilaku kesehatannya. ${ }^{6}$

Green dalam bukunya yang berjudul "Health Education Planing A Diagnostik Approach" menyatakan bahwa adapun faktorfaktor yang memengaruhi perilaku kesehatan individu terbagi atas 3 faktor yaitu: 1) faktor predisposisi (predisposing factors) yang mencakup pengetahuan, sikap, tindakan yang terdapat dalam diri individu dan masyarakat. 2) Faktor pendukung (enabling factors) adalah tersedianya sarana pelayanan kesehatan dan kemudahan untuk mencapainya. 3) Faktor pendorong (reinforcing factors) adalah pengaruh lingkungan.

Pada penelitian ini, peneliti tertarik untuk melakukan penelitian tentang faktor-faktor yang memengaruhi perilaku masyarakat dalam pemberantasan malaria di Desa Sekerak Kanan Kecamatan Sekerak.Kecamatan Sekerak merupakan salah satu kecamatan di Kabupaten Aceh Tamiang yang tidak tereliminasi malaria sehingga rentan mengalami kejadian malaria.Desa ini memiliki beberapa lokasi yang terletak di daerah berawa dan ditumbuhi banyak semak yang memungkinkan untuk tempat berkembangbiaknya vektor malaria, selain faktor lingkungan yang mendukung perkembangbiakan nyamuk, juga perilaku masyarakat seperti kebiasaan keluar rumah pada malam hari, tidak menggunakan kelambu. Hal ini disebabkan oleh kurangnya promosi kesehatan yang dilakukan oleh tenaga kesehatan tentang malaria di Desa Sekerak Kanan Kecamatan Sekerak Kabupaten Aceh Tamiang.

Berdasarkan survey awal tersebut, peneliti tertarik untuk mengetahui bagaimana perilaku kesehatan masyarakat di Desa Sekerak Kanan Kecamatan Sekerak Kabupaten Aceh Tamiang dalam memberantas kejadian malaria. Oleh sebab itu, pada penelitian ini peneliti menggunakan teori Green yang dikenal dengan teori precede procede untuk mengetahui bagaimana pengetahuan masyarakat Desa 
Sekerak Kanan Kecamatan Sekerak Kabupaten Aceh Tamiang tentang malaria, bagaimana sikap dan tindakan mereka, apakah pekerjaan dan penghasilan mereka memengaruhi mereka dalam memberantas malaria, dan bagaimana ketersediaan sarana prasarana untuk memberantas malaria cukup baik, serta bagaimana peran lingkungan tempat tinggal dan penyuluhan petugas kesehatan di Desa Sekerak Kanan Kecamatan Sekerak Kabupaten Aceh Tamiang dalam rangka pemberantasan malaria. Berdasarkan paparan di atas, peneliti tertarik untuk melakukan penelitian dengan judul penelitian "Faktor yang Memengaruhi Perilaku Masyarakat dalam Pemberantasan Malaria di Desa Sekerak Kanan Kecamatan Sekerak Kabupaten Aceh Tamiang Tahun 2019".

\section{BAHAN DAN METODE}

Penelitian ini menggunakan jenis penelitian kuantitatif dengan rancangan cross sectional study. Lokasi penelitian ini dilakukan di di Desa Sekerak Kanan Kecamatan Sekerak Kabupaten Aceh Tamiang. Waktu Penelitian adalah Populasi penelitian kuantitatif yaitu seluruh ibu rumah tangga yang berdomisili di Desa Sekerak Kanan Kecamatan Sekerak Kabupaten Aceh Tamiang dengan jumlah sebanyak 97 orang ibu.Teknik yang digunakan adalah total sampling berjumlah 97 orang.Data hasil survey dianalisis dengan menggunakan uji Chi Square dan regresi logistik.

\section{HASIL}

Analisis Data Univariat

Berdasarkan data yang diperoleh dari hasil penelitian dengan 97 responden dapat dilihat dalam tabel distribusi frekuensi sebagai berikut.

Tabel 1.Distribusi Karakteristik Responden Berdasarkan Umur, Jenis Kelamin, Pendidikan, Pekerjaan

\begin{tabular}{ccc}
\hline Umur & F & $\%$ \\
\hline 17-25 Tahun & 2 & 2,06 \\
26-35 Tahun & 35 & 36,08 \\
36-45 Tahun & 31 & 31,96 \\
46-55 Tahun & 29 & 29,90 \\
\hline Pendidikan & & \\
\hline SMP & 29 & 29,90 \\
SMA & 45 & 46,39 \\
PT & 23 & 23,71 \\
\hline Pekerjaan & & \\
\hline Petani & 39 & 40,21 \\
Wiraswasta & 32 & 32,99 \\
PNS & 26 & 26,80 \\
\hline Total & $\mathbf{9 7}$ & \\
\hline
\end{tabular}

Berdasarkan tabel 1 di atas diketahui bahwa dari 97 responden, diketahui bahwa dari 97 ibu rumah tangga yang diteliti, diketahui bahwa sebagian besar ibu rumah tanggaberumur 26-35 tahun yaitu sebanyak 35 $(36,08 \%)$ orang. Sedangkan ibu rumah tanggalainnya berumur 17-25 tahun yaitu sebanyak $2(2,06 \%)$ orang, yang berumur 36-45 tahun yaitu sebanyak $31(31,96 \%)$ orang, dan yang berumur 46-55 tahun yaitu sebanyak 29 $(29,90 \%)$ orang.

Adapun distribusi frekuensi ibu rumah tanggaberdasarkan pendidikan, diketahui bahwa sebagian besar ibu rumah tangga berpendidikan SMA yaitu sebanyak 45 (46,39\%) orang, sedangkan ibu rumah tanggalainnya berpendidikan SMP yaitu sebanyak 29 (29,90\%) orang, yang berpendidikan PT yaitu sebanyak $23(23,71 \%)$ orang.

Adapun distribusi frekuensi ibu rumah tanggaberdasarkan pekerjaan, diketahui bahwa sebagian besar ibu rumah tanggamemiiliki pekerjaan sebagai petani yaitu sebanyak 39 $(40,21 \%)$ orang, sedangkan ibu rumah tanggalainnya memiliki pekerjaan sebagai wiraswasta yaitu sebanyak 32 (32,99\%) orang , dan yang bekerja sebagai PNS yaitu sebanyak $26(26,80 \%)$ orang.

\section{Analisis Data Bivariat}

Untuk mengetahuiperilaku masyarakatdalam pemberantasan malaria. 
Tabel 2.Analisis Pemberantasan Malaria di Desa Sekerak Kanan Kecamatan Sekerak Kabupaten Aceh Tamiang Tahun 2019

\begin{tabular}{|c|c|c|c|c|c|c|c|}
\hline \multirow{3}{*}{ Pengetahuan } & \multicolumn{6}{|c|}{ Kejadian Malaria } & \multirow{2}{*}{ p value } \\
\hline & \multicolumn{2}{|c|}{ Tidak } & \multicolumn{2}{|c|}{ Ya } & \multicolumn{2}{|c|}{ Total } & \\
\hline & $\mathbf{n}$ & $\%$ & $\mathbf{n}$ & $0^{\circ}$ & $\mathbf{n}$ & $\%$ & \\
\hline Kurang & 43 & 44,33 & 10 & 10,31 & 53 & 54,64 & 0,045 \\
\hline Baik & 35 & 36,08 & 9 & 9,28 & 44 & 45,36 & \\
\hline
\end{tabular}

\begin{tabular}{|c|c|c|c|c|c|c|c|}
\hline \multirow{3}{*}{ Sikap } & \multicolumn{6}{|c|}{ Kejadian Malaria } & \multirow{3}{*}{ p value } \\
\hline & \multicolumn{2}{|c|}{ Tidak } & \multicolumn{2}{|c|}{$\mathrm{Ya}$} & \multicolumn{2}{|c|}{ Total } & \\
\hline & $\mathbf{n}$ & $\%$ & $\mathbf{n}$ & $\%$ & $\mathbf{n}$ & $\%$ & \\
\hline Negatif & 48 & 49,48 & 8 & 8,25 & 56 & 57,73 & 0,024 \\
\hline \multirow[t]{2}{*}{ Positif } & 30 & 30,93 & 11 & 11,34 & 41 & 42,27 & \\
\hline & \multicolumn{6}{|c|}{ Kejadian Malaria } & \\
\hline \multirow[t]{2}{*}{ Kemampuan Ekonomi } & \multicolumn{2}{|c|}{ Tidak } & \multicolumn{2}{|c|}{$\mathrm{Ya}$} & \multicolumn{2}{|c|}{ Total } & p value \\
\hline & $\mathbf{n}$ & $\%$ & $\mathbf{n}$ & $\%$ & $\mathbf{n}$ & $\%$ & \\
\hline Rendah & 47 & 48,45 & 7 & 7,22 & 54 & 55,67 & 0,015 \\
\hline Tinggi & 41 & 42,27 & 12 & 12,37 & 43 & 44,33 & \\
\hline
\end{tabular}

\begin{tabular}{|c|c|c|c|c|c|c|c|c|}
\hline \multirow{3}{*}{$\begin{array}{l}\text { Lingkungan } \\
\text { Tinggal }\end{array}$} & \multirow{3}{*}{ Tempat } & \multicolumn{6}{|c|}{ Kejadian Malaria } & \multirow{2}{*}{ p value } \\
\hline & & \multicolumn{2}{|c|}{ Tidak } & \multicolumn{2}{|c|}{$\mathrm{Ya}$} & \multicolumn{2}{|c|}{ Total } & \\
\hline & & r & $\%$ & $\mathbf{n}$ & $\%$ & $\mathbf{n}$ & $\%$ & \\
\hline Tidak Perduli & & 49 & 50,52 & 13 & 13,40 & 62 & 63,92 & 0,025 \\
\hline Perduli & & 29 & 29,89 & 6 & 6,19 & 35 & 36,08 & \\
\hline
\end{tabular}

\begin{tabular}{|c|c|c|c|c|c|c|c|c|}
\hline \multirow{3}{*}{$\begin{array}{l}\text { Penyuluhan } \\
\text { Kesehatan }\end{array}$} & \multirow{3}{*}{ Tenaga } & \multicolumn{6}{|c|}{ Kejadian Malaria } & \multirow{3}{*}{ p value } \\
\hline & & \multicolumn{2}{|c|}{ Tidak } & \multicolumn{2}{|c|}{$\mathrm{Ya}$} & \multicolumn{2}{|c|}{ Total } & \\
\hline & & $\mathbf{n}$ & $\%$ & $\mathbf{n}$ & $\%$ & $\mathbf{n}$ & $\%$ & \\
\hline Tidak Perduli & & 48 & 49,48 & 11 & 11,34 & 59 & 60,82 & 0,005 \\
\hline Perduli & & 30 & 30,93 & 8 & 8,25 & 38 & 39,18 & \\
\hline
\end{tabular}

Berdasarkan tabel 2 di atas diketahui bahwa dari 97 ibu rumah tangga yang diteliti, sebagian besar ibu rumah tangga yang diteliti memiliki pengetahuan kurang yaitu sebanyak 53 $(54,64 \%)$ orang . Dari $53(54,64 \%)$ ibu rumah tangga tersebut, ada sebanyak $43(44,33 \%)$ orang memiliki pengetahuan kurang dan tidak mengalami kejadian malaria, sebanyak 10 $(10,31 \%)$ ibu rumah tangga yang memiliki pengetahuan kurang dan mengalami kejadian malaria. Berdasarkan hasil perhitungan uji statistik diperoleh nilai $p$ significancy yaitu $0,045<0,05$, sehingga dapat disimpulkan bahwa ada pengaruh pengetahuan masyarakat terhadap pemberantasan malaria di Desa Sekerak Kanan Kecamatan Sekerak Kabupaten Aceh Tamiang Tahun 2019.

Dari 97 ibu rumah tangga yang diteliti, sebagian besar ibu rumah tangga yang diteliti memiliki sikap negatif yaitu sebanyak 56 $(57,73 \%)$ orang . Dari $56(57,73 \%)$ ibu rumah tangga tersebut, ada sebanyak $48(49,48 \%)$ orang memiliki sikap negatif dan tidak mengalami kejadian malaria, sebanyak 8 $(8,25 \%)$ ibu rumah tangga yang memiliki sikap negatif dan mengalami kejadian malaria. Berdasarkan hasil perhitungan uji statistik diperoleh nilai $p$ significancy yaitu $0,024<0,05$, sehingga dapat disimpulkan bahwa ada pengaruh sikap masyarakat terhadap pemberantasan malaria di Desa Sekerak Kanan Kecamatan Sekerak Kabupaten Aceh Tamiang Tahun 2019.

Dari 97 ibu rumah tangga yang diteliti, sebagian besar ibu rumah tangga yang diteliti memiliki kemampuan ekonomi rendah yaitu sebanyak 54 (55,67\%) orang . Dari 54 (55,67\%) ibu rumah tangga tersebut, ada sebanyak 47 $(48,45 \%)$ orang memiliki kemampuan ekonomi rendah dan tidak mengalami kejadian malaria, sebanyak $7(7,22 \%)$ ibu rumah tangga yang memiliki kemampuan ekonomi rendah dan mengalami kejadian malaria. Berdasarkan hasil perhitungan uji statistik diperoleh nilai 
psignificancy yaitu $0,015<0,05$, sehingga dapat disimpulkan bahwa ada pengaruh kemampuan ekonomi masyarakat terhadap pemberantasan malaria di Desa Sekerak Kanan Kecamatan Sekerak Kabupaten Aceh Tamiang Tahun 2019.

Dari 97 ibu rumah tangga yang diteliti, sebagian besar ibu rumah tangga yang diteliti tidak perduli dengan lingkungan tempat tinggal yaitu sebanyak $62(63,92 \%)$ orang . Dari 62 $(63,92 \%)$ ibu rumah tangga tersebut, ada sebanyak $49(50,52 \%)$ orang tidak perduli dengan lingkungan tempat tinggal dan tidak mengalami kejadian malaria, sebanyak 13 $(13,40 \%)$ ibu rumah tangga yang tidak perduli dengan lingkungan tempat tinggal dan mengalami kejadian malaria. Berdasarkan hasil perhitungan uji statistik diperoleh nilai $p$ significancy yaitu $0,025<0,05$, sehingga dapat disimpulkan bahwa ada pengaruh lingkungan tempat tinggal masyarakat terhadap pemberantasan malaria di Desa Sekerak Kanan Kecamatan Sekerak Kabupaten Aceh Tamiang Tahun 2019.
Dari 97 ibu rumah tangga yang diteliti, sebagian besar ibu rumah tangga yang diteliti tidak perduli dengan penyuluhan tenaga kesehatanyaitu sebanyak $59(60,82 \%)$ orang . Dari $59(60,82 \%)$ ibu rumah tangga tersebut, ada sebanyak $48(49,48 \%)$ orang tidak perduli dengan penyuluhan tenaga kesehatandan tidak mengalami kejadian malaria, sebanyak 11 $(11,34 \%)$ ibu rumah tangga yang tidak perduli dengan penyuluhan tenaga kesehatandan mengalami kejadian malaria. Berdasarkan hasil perhitungan uji statistik diperoleh nilai $p$ significancy yaitu $0,005<0,05$, sehingga dapat disimpulkan bahwa ada pengaruh penyuluhan tenaga kesehatanmasyarakat terhadap pemberantasan malaria di Desa Sekerak Kanan Kecamatan Sekerak Kabupaten Aceh Tamiang Tahun 2019.

\section{Analisis Multivariat}

Adapun variable mana yang paling dominan berpengaruh adalah:

Tabel 3.Analisis Pemberantasan Malaria di Desa Sekerak Kanan Kecamatan Sekerak Kabupaten Aceh Tamiang Tahun 2019

\begin{tabular}{clcccc}
\hline No & Variabel & B & P vlue & Exp(B)OR & 95\%Cl for Exp(B) \\
\hline 1 & Sikap & 0,669 & 0,207 & 1,953 & $0,690-5,525$ \\
2 & Kemampuan & 0,862 & 0,008 & 2,368 & $0,827-6,783$ \\
& ekonomi & & & &
\end{tabular}

Berdasarkan tabel 3 diatas dapat dilihat bahwa analisis regresi logistik menghasilkan 1 (satu) variabel yang paling berpengaruh dalam pemberantasan malaria di Desa Sekerak Kanan Kecamatan Sekerak Kabupaten Aceh Tamiang Tahun 2019, yaitu variabel kemampuan ekonomi. dengan nilai $\mathrm{p}$ signifikan 0,008 ( $\mathrm{p}$ value $<0,05), \mathrm{OR}=2,368(95 \% \mathrm{Cl}=0,827-6,783)$ artinya ibu rumah tangga yang memiliki kemampuan ekonomi rendah mempunyai

\section{PEMBAHASAN}

Pada penelitian ini, peneliti menetapkan ibu rumah tangga yang ada di Desa Sekerak Kanan Kecamatan Sekerak Kabupaten Aceh Tamiang menjadi responden. Adapun alasan peneliti memilih ibu rumah tangga, karena orang yang hampir setiap hari berada di dalam rumah adalah seorang ibu, dan seorang ibu jugalah yang sering melakukan kegiatan bersih-bersih di dalam rumah dan pekarangan.Akan tetapi tidak semua ibu mampu melakukannya, adapun beberapa faktor yang memengaruhi ibu dalam peluang 2,368 kali terhadap kejadian malaria, bila dibandingkan dengan ibu rumah tangga yang memiliki kemampuan ekonomi tinggi. Nilai koefisien B yaitu 0,862 bernilai positif, yang artinya semakin rendah kemampuan ekonomi ibu rumah tangga maka semakin tinggi pula angka kejadian malaria di Desa Sekerak Kanan Kecamatan Sekerak Kabupaten Aceh Tamiang Tahun 2019.

melakukan kegiatan bersih-bersih yaitu umur, pendidikan dan pekerjaan.

Umur merupakan salah satu faktor yang berhubungan dengan pemberantasan malaria, semakin tua usia ibu maka semakin sadar akan kesehatan lingkungannya dan sebaliknya. Hasil penelitian menunjukkan bahwa dari 97 ibu rumah tangga yang diteliti, diketahui bahwa sebagian besar ibu rumah tanggaberumur 26-35 tahun yaitu sebanyak $35(36,08 \%)$ orang. Ibu yang berusia 26-35 tahun artinya adalah ibu muda dan masih memiliki anak dan cenderung 
lebih memikirkan kesehatan anak daripada kebersihan rumah dan lingkungan.

Menurut asumsi peneliti, tingkat pendidikan ibu yang menjadi responden dalam penelitian ini memang hanya sebatas jenjang SMA, tetapi ibu tersebut harus dapat meningkatkan pengetahuan tentang kesehatan, misalnya dengan cara mengikuti penyuluhan, dan sering membuka informasi yang tersedia secara terbuka di media internet dan hal tersebut dapat memberi kontribusi terhadap meningkatnya pengetahuan ibu, dalam hal ini diharapkan dapat bersikap positif dan mewujudkan kesadaran yang tinggi dan berperilaku baik dalam melakukan pencegahan malaria.

Berdasarkan hasil penelitian yang dilakukan di Desa Sekerak Kanan Kecamatan Sekerak Kabupaten Aceh Tamiang Tahun 2019, diketahui bahwa dari 97 ibu rumah tangga yang diteliti, sebagian besar ibu rumah tanggamemiliki pengetahuan kurang yaitu sebanyak 53 $(54,64 \%)$ orang.

Berdasarkan hasil penelitian, rata-rata masyarakat kurang tahu apa yang menyebabkan banyaknya nyamuk yang menyebarkan penyakit malaria, yaitu nyamuk yang bersarang di dalam genangan air, di rumput yang tinggi, baju yang bergantungan dan rumah yang tidak rapi. Selama mengumpulkan data, peneliti melihat bahwa banyak genangan air di sekitar halaman rumah responden, bahkan rumput liar yang ada dipekarangan rumah dibiarkan tumbuh memanjang karena mengaku tidak sempat memotong rumput tersebut karena sibuk mengurus anak dan suami, bahkan rumahrumah mereka cenderung berantakan dan banyak dijumpai rumah yang kurang rapi.

Menurut asumsi peneliti, ibu-ibu Desa Sekerak Kanan perlu untuk meningkatkan pengetahuannya tentang pencegahan malaria.Adapun upaya yang perlu dilakukan oleh ibu yaitu, membersihkan pekarangan rumah, dan mengurangi penggantungan baju yang menungkinkan nyamuk dapat hinggap di baju tersebut.

Sikap ibu merupakan bagian dari kehidupan yang tentu sulit untuk ditinggalkan begitu saja, Hasil penelitian di Desa Sekerak Kanan kecamatan Sekerak Kabupaten Sekerak Kanan menunjukkan bahwa dari 97 ibu rumah tanggayang diteliti, sebagian ibu rumah tanggamemiliki sikap negatif yaitu sebanyak 56 $(57,73 \%)$ orang. Sikap negatif tersebut ditunjukkan melalui kurangnya sikap ibu dalam menjaga dan memelihara kebersihan lingkungan untuk mencegah perkembangbiakan nyamuk penular penyakit malaria, misalnya dengan membersihkan pekarangan yang ditumbuhi rumput liar, membiarkan wadah-wadah yang memungkinkan tergenangnya air hujan sehingga nyamuk dapat bertelur di dalamnya.

Menurut asumsi peneliti, sebaiknya ibu -ibu lebih bersikap positif terhadap pencegahan kejadian malaria karena sebenarnya malaria dapat dikurangi, misalnya dengan kepedulian ibu terhadapa kebersihan lingkungan, mengurangi kebiasaan keluar rumah pada malam hari, menggunakan kelambu yang baik saat tidur, membiasakan anak-anak untuk berpakaian, dan tidak menggantungkan pakaian secara berlebihan.

Ketidakmampuan ekonomi berperan dalam penyebaran penyakit infeksi dari berbagai macam penyakit menular seperti malaria, hal ini dikarenakan kemiskinan secara absolut ditentukan berdasarkan ketidakmampuan untuk mencukupi kebutuhan pokok minimum seperti pangan, sandang, kesehatan, perumahan dan pendidikan yang diperlukan untuk bisa hidup.Kejadian malaria dihubungkan dengan kemiskinan sekaligus sebagai penyebab dan akibat.Malaria sangat memengaruhi kondisi penduduk miskin di daerah terpencil yang jauh dari lingkungan pelayanan kesehatan. ${ }^{5,7}$

Hasil penelitian di Desa Sekerak Kanan Kecamatan Sekerak Kabuapten Aceh Tamiang menunjukkan bahwa dari 97 ibu rumah tanggayang diteliti, sebagian besar ibu rumah tangga memiliki kemampuan ekonomi rendahyaitu sebanyak $54(55,67 \%)$ orang. Ibu yang memiliki kemampuan ekonomi rendah cenderung tidak memperhatikan kebutuhan kesehatan, hal ini dikarenakan kesulitan dalam memenuhi kebutuhan pangan sehari-hari, dengan demikian kondisi rumah masyarakat yang memiliki kemampuan ekonomi rendah hanya terbuat dari bahan murahan yang menyebabkan nyamuk dapat masuk dalam rumah dan terjadi infeksi dalam rumah.Sehingga walaupun aktivitas malam hari hanya dilakukan dalam rumah, nyamuk malaria tetap dapat masuk.lbu yang memiliki kemampuan ekonomi rendah juga menyebabkan tidak terpenuhinya kebutuhan gizi secara seimbang sehingga daya tahan tubuh terhadap penyakit malaria rendah sehingga mudah terserang penyakit malaria.

Berdasarkan asumsi peneliti, meskipun suatu keluarga memiliki kemampuan ekonomi yang rendah, namun pencegahan malaria tetap masih dapat dilakukan, seperti menjaga kebersihan lingkungan pekarangan dan lingkungan rumah.Kesehatan itu tidaklah mahal, 
yang mahal adalah waktu dan keinginan untuk dapat terus hidup sehat.

Menurut Widoyono, ada tiga faktor utama yang saling berhubungan dengan kejadian malaria, yaitu host (manusia/nyamuk), agent (parasit plasmodium) dan environment (lingkungan). Kejadian malaria terjadi apabila ketiga komponen tersebut saling mendukung. Sebagai host intermediete, manusia bisa terinfeksi oleh agent dan merupakan tempat berkembang biaknya nyamuk Semua itu dipengaruhi oleh usia, jenis kelamin, ras, sosial ekonomi, status perkawinan, riwayat penyakit sebelumnya, gaya dan cara hidup, hereditas (keturunan), status gizi dan tingkat imunitas. ${ }^{3}$

Hasil penelitian menunjukkan bahwa dari 97 ibu rumah tangga yang diteliti, sebagian besar ibu rumah tangga tidak perduli dengan lingkungan tempat tinggal yaitu sebanyak 62 $(63,92 \%)$ orang. Sedangkan ibu rumah tangga yang lainnya perduli dengan lingkungan tempat tinggal yaitusebanyak $35(36,08 \%)$ orang.

Sebagai salah satu penyakit yang dapat menular kembali secara massal, malaria hingga saat ini menjadi ancaman serius bagi masyarakat yang tinggal di daerah tropis dan subtropis.Di dua kawasan tersebut, malaria sering menimbulkan kejadian luar biasa (KLB) dengan jumlah kematian mencapai lebih dari satu juga orang setiap tahunnya. Hal ini sejalan dengan survey awal yang dilakukan oleh peneliti di Desa Sekerak Kanan Kecamatan Sekerak Kabupaten Aceh Tamiang dengan melihat data sekunder yang ada di Puskesmas Sekerak Kanan tahun 2019, diketahui bahwa terdapat 11 kejadian malaria di Desa Sekerak Kanan Kecamatan Sekerak Kabupaten Aceh Tamiang. Dari 11 orang tersebut, 3 orang diantaranya meninggal dunia yaitu 1 orang ibu hamil dan 2 orang lainnya anak usia sekolah dasar.

Kejadian malaria juga besar kemungkinan disebabkan oleh pengaruh lingkungan tempat tinggal. Pada saat melakukan penelitian di Desa Sekerak Kanan diketahui bahwa masyarakat ada yang memiliki kolam ikan, sehingga apabila ada jentik nyamuk tidak akan bertahan lama, kemudian masyarakat juga hidup rukun dan saling mendukung dalam hal gotong royong misalnya dengan dilakukannya jumat bersih di Desa.

Namun meskipun demikian, ada juga masyarakat di lingkungan Desa Sekerak Kanan yang tidak menyukai hidup bersih.Ada beberapa rumah tangga yang tinggal dipinggir sungai yang tidak menjaga kebersihan pekarangannya, banyak sampah yang berserakan dan botol-botol aqua yang sengaja dikumpul untuk dijual kembali, namun tidak disimpan rapi misalnya dengan memasukkannya ke dalam karung.Masyarakat tersebut lebih memilih menumpuk botol-botol aqua.

Penelitian ini sejalan dengan penelitian yang dilakukan Gilang (2015). Berdasarkan hasil analisis dapat disimpulkan bahwa apabila kepala keluarga belum pernah terkena malaria dan memiliki pekerjaan beresiko memiliki kemungkinan pencegahan rendah sebesar 60,6 $\%$. Instansi kesehatan perlu melakukan penyuluhan secara berkala kepada masyarakat Kecamatan Rajabasa terkait perilaku nyamuk Anophelessp, cara pemberantasan nyamuk, pengobatan penyakit malaria dan pencegahan terhadap penyakit malaria, sehingga masyarakat tahu dan mau mencegah penyakit malaria secara konsisten.

Menurut asumsi peneliti, sebagai masyarakat yang bertempat tinggal di daerah endemis malaria baik daerah yang kategori daerah endemis malaria tinggi dan daerah endemis malaria sedang, masyarakat perlu mengetahui kesehatan lingkungan dengan cara mempelajari dan menangani hubungan manusia dengan lingkungan dalam keseimbangan ekosistem dengan tujuan meningkatkan derajat kesehatan masyarakat yang optimal melalui pencegahan terhadap penyakit dan gangguan kesehatan dengan mengendalikan faktor lingkungan yang dapat menyebabkan timbulnya penyakit. Interaksi lingkungan dengan pembangunan saatini maupun yang akan datang saling berpengaruh.

Hasil penelitian menunjukkan bahwa dari 97 ibu rumah tangga yang diteliti, sebagian besar ibu rumah tangga tidak perduli dengan penyuluhan tenaga kesehatan yaitu sebanyak 59 $(60,82 \%)$ orang. Sedangkan ibu rumah tangga yang lainnya perduli dengan penyuluhan tenaga kesehatan yaitu sebanyak $38(39,18 \%)$ orang.

Berdasarkan hasil penelitian peneliti di Desa Sekesrak Kanan, peran petugas kesehatan sangat menentukan dalam memutus mata rantai siklus hidup nyamuk malaria.Salah satu bentuk intervensi petugas kesehatan yang dilakuakn di Desa Sekerak Kanan yaitu memberikan penyuluhan kesehatan tentang pemberantasan sarang nyamuk penyebab malaria.Penyuluhan kesehatan masyarakat bertujuan agar masyarakat menyadari mengenai masalah penanggulangan dan pemberantasan malaria, sehingga mengubah pola perilaku untuk hidup sehat dan bersih. 
Akan tetapi petugas kesehatan sangat jarang sekali melakukan penyuluhan, sehingga tidak banyak informasi yang diperoleh masyarakat tentang kejadian malaria tersebut.Masyakat lebih banyak mendapatkan informasi tentang upaya pemberantasan malaria dari lingkungan seperti tetangga dan dari sosial media.Padahal Aspek fisik dalam hal ini petugas kesehatan, perannya sangat penting dimana mampu mendukung terciptanya suatu pelayanan kesehatan yang memadai bagi masyarakat.Pelayanan kesehatan merupakan salah satu parameter untuk mengetahui status kesehatan masyarakat.

Berdasarkan teori Bloom, salah satu faktor yang mempengaruhi kesehatan manusia adalah pelayanan kesehatan.Dengan kata lain berfungsinya pelayanan kesehatan dengan baik di suatu daerah mampu meningkatkan derajat kesehatan masyarakat di daerah tersebut. $(6,4)$

Menurut asumsi peneliti, sebaiknya petugas kesehatan harus sering melakukan penyuluhan tentang penyebab malaria, agar memberikan informasi yang tepat tentang pencegahan malaria, misalnya dengan memaparkan tentang penyebab dan cara pencegahan malaria dengan menggunakan media yang tepat dan sering mengajak masyarakat di lingkungan Anda untuk melaksanakan program gotong royong

\section{KESIMPULAN DAN SARAN}

Adapun kesimpulan dalam penelitian ini yaitu pengetahuan, sikap, kemampuan ekonomi, lingkungan tempat tinggal, penyuluhan tenaga kesehatanmasyarakat, berpengaruh dalam pemberantasan malaria di Desa Sekerak Kanan Kecamatan Sekerak Kabupaten Aceh Tamiang Tahun 2019. Sehingga disarankan agar masyarakat dapat meningkatkan wawasan, pengetahuan, keterampilan dalam mengumpulkan, mengolah, menganalisa serta menginformasikan data temuan tentang perilaku masyarakat dalam pemberantasan malaria.

\section{REFERENSI}

1. Septiana, Eris. Bioteknologi Sebagai Senjata Menghadapi Serangan Malaria. Biotrends; 2016, 7.2: 18-23.

2. World Health Organization. World Malaria Report 2015. World Health Organization; 2018.

3. Kementerian Kesehatan Republik Indonesia,, Et Al. Direktorat Jenderal Pengendalian Penyakit Dan Penyehatan Lingkungan. Pedoman Umum
Kesiapsiagaan Menghadapi Middle East Respiratory Syndrome-Corona Virus (MersCov); 2018.

4. Roosihermiatie, Betty; Rukmini, Rukmini. Analisis Implementasi Kebijakan Eliminasi Malaria. Buletin Penelitian Sistem Kesehatan; 2018, 15.2 Apr.

5. Publik, Layanan. Informasi Publik; 2015.

6. Lawrence G. Health Promotion Planning An Educational And Environmental Approach. Mayfield Publishing Company. London : Mountain View-Toronto; 2011.

7. Husin, Hasan. Analisis Faktor Risiko Kejadian Malaria Di Puskesmas Sukamerindu Kecamatan Sungai Serut Kota Bengkulu Propinsi Bengkulu. 2010. Phd Thesis. Program Pascasarjana Universitas Diponegoro. 